\title{
PERAN PSYCHOLOGICAL DETACHMENT SEBAGAI MODERATOR HUBUNGAN STRES KERJA DAN KINERJA
}

\author{
Abi Dinda Permata Sari', Rostiana ${ }^{2}$, Daniel Lie $^{3}$ \\ ${ }^{1}$ Fakultas Psikologi, Universitas Tarumanagara, Jakarta \\ Email: abidindaps@gmail.com \\ ${ }^{2}$ Fakultas Psikologi, Universitas Tarumanagara, Jakarta \\ Email: dutaindah03@yahoo.com \\ ${ }^{3}$ Fakultas Psikologi, Universitas Tarumanagara, Jakarta \\ Email: daniel.lie@livel.com
}

\begin{abstract}
ABSTRAK
Penelitian ini bertujuan untuk mengetahui peran psychological detachment sebagai moderator hubungan antara stres kerja dan kinerja. Penelitian ini melibatkan 100 partisipan yang terdiri dari 39 yang sudah menikah, dan 61 partisipan belum menikah. Partisipan berasal dari berbagai macam jenis perusahaan yang bergerak dalam keuangan, media, makanan minuman, dan yang lainnya. Berdasarkan hasil penelitian dengan menggunakan uji interaksi dari metode korelasi Pearson hasilnya, didapatkan pada kelompok psychological detachment rendah, hubungan stres kerja dan kinerja menunjukan angka negatif $r=-0,422$ dan $p=0,023<0,05$. Hal serupa juga terjadi pada kelompok partisipan dengan psychological detachment tinggi, hubungan stres kerja dan kinerja adalah negatif $r=-0,443$ dan $p=0,013<0,05$. Penelitian menunjukkan bahwa psychological detachment tidak berfungsi sebagai moderator dalam hubungan stres kerja dengan kinerja.
\end{abstract}

Kata kunci: job stress, job performance, psychological detachment

\section{PENDAHULUAN \\ Latar Belakang}

Tahun 2015, Indonesia masuk dalam Masyarakat Ekonomi Asia (MEA) beserta dengan sembilan negara anggota Assosiation of Southeast Asian Nation (ASEAN) lainnya. Berkaitan dengan hal tersebut, seluruh negara harus membuat sebuah persiapan yang baik dalam mempersiapkan kompetensi dari para tenaga kerja agar dapat bersaing dengan tenaga kerja lain dari negara lain untuk menghasilkan produktivitas yang lebih baik (Suryanto, 2015). Pemerintah Indonesia melakukan sejumlah usaha untuk mempersiapkan persaingan di pasar bebas ini dengan melakukan pembuatan kebijakan mengenai 85 standar kompetensi kerja nasional Indonesia (SKKNI) dan melakukan akreditasi di 725 balai pelatihan kerja dan lembaga pelatihan kerja swasta (Rostanti \& Rini, 2016)

Tahun 2016, kebijakan dari MEA mulai diterapkan di negara-negara ASEAN. Sebagai konsekuensi dari kebijakan ini dapat memicu pertumbuhan ekonomi dan berdampak pada meningkatnya persaingan dunia usaha baik secara nasional maupun internasional (Mukhlis, diunduh dari Tribunnews, 2016). Perusahaan harus mampu mengikuti persaingan ini demi kelanjutan organisasinya. Ketika perusahaan tidak mampu untuk mengikuti persaingan ini, dampaknya dapat membuat perusahaan kalah dan membuat perusahaan tidak dapat mempertahankan kelanjutan usahanya. Perusahaan harus dapat menyesuaikan diri dan berkembang agar dapat terus bersaing pada era ini. Hal ini tentu tidak akan terlepas dari peran karyawan sebagai motor penggerak dari perusahaan. Semakin baik seorang kerja dalam mengerjakan tugasnya, tentu akan semakin besar pula kesempatan bagi perusahaan untuk dapat bersaing dan bertahan dalam persaingan yang ada (Hartanto dalam Agustina, 2016),

Karyawan merupakan ujung tombak dari roda perputaran di perusahaan, karyawan yang ada di perusahaan harus senantiasa meningkatkan performa kerjanya untuk terus mengikuti persaingan 
besar ini (Hartanto dalam Agustina, 2016). Koopsman (2014) mendefinisikan kinerja pola perilaku dan tindakan dari para karyawan yang relevan dengan tujuan organisasi Terdapat beberapa faktor dari performa kerja dari para karyawan. Pertama, karyawan harus mampu melakukan hal yang sudah menjadi tugasnya sesuai dengan posisi masing-masing. Hal ini merupakan hal yang mutlak diperlukan oleh karyawan, yaitu melaksanakan tugasnya. Selain dilihat langsung dari tugasnya, terdapat juga performa kerja dari karyawan yang bekerja. Kedua, seorang karyawan perlu melakukan hal yang menunjukkan rasa memiliki terhadap perusahaan sehingga dirinya juga bersedia melakukan usaha seperti membantu orang lain dalam pekerjaan. Ketiga, karyawan juga menunjukkan performa kerjanya dengan menghindari perbuatan merugikan perusahaan, seperti memanfaatkan waktu yang seharusnya untuk bekerja namun digunakan untuk bermain. Hal yang merugikan ini dapat berupa perilaku pada organisasi langsung, maupun kepada individu di tempat kerja Keempat, peforma kerja juga dilihat dari individu di tempat kerja mau dan mampu beradaptasi dengan perubahan yang ada di perusahaan. Hal ini dibutuhkan karena dilihat juga bahwa persaingan yang semakin kuat ini dipengaruhi oleh perkembangan teknologi. Perubahan ini membuat karyawan perlu menyesuaikan diri dengan kondisi baru, dengan kata lain, karyawan harus mampu mengikuti perkembangan dari menjadi up to date dengan kondisi perkembangan yang ada saat ini. Kemampuan ini perlu dimiliki oleh setiap karyawan yang ada di perusahaan agar perusahaan dapat terus berkembang dan mengikuti persaingan di pasar bebas yang ada (Koopsman, 2014)

Seiring dengan kemajuan globalisasi, wanita semakin menyadari kemampuannya untuk menjadi setara dengan laki-laki dalam ekspektasi menimba ilmu dan mengedukasi dirinya. Kondisi era globalisasi ini mendorong wanita untuk giat bekerja setelah menginjak usia dewasa, wanita lebih memilih bekerja dibandingkan hanya menjadi ibu rumah tangga setelah menikah. Kemampuaan bekerja dapat meningkatkan keberhargaan seorang wanita dan memberikan kemapanan ekonomi bagi wanita itu sendiri (Aleem \& Danish, 2008).

Karyawan yang sudah menikah dan memiliki anak tentu memiliki tuntutan yang lebih banyak. Sepulang bekerja dan di akhir pekan, seorang karyawan yang sudah menikah memiliki tanggung jawab terhadap keluarga dan anaknya. Tidak sedikit yang mengeluhkan bahwa dirinya kewalahan dalam membagi waktunya. Para karyawan ini terkadang merasa lelah sepulang bekerja, tetapi tidak dapat langsung beristrihat. Adanya fenomena ini tentu membuat seorang karyawan harus mampu mengolah waktu agar dapat tetap bekerja dengan optimal. Menurut komunikasi personal dengan seorang manajer marketing sebuah perusahaan Jepang yang ada di Indonesia, dirinya merasa sulit membagi waktu antara keluarga dan pekerjaannya. Subyek ini mengatakan bahwa dirinya berangkat kerja pada pukul 06.00, dan pulang ke rumah menjelang pukul 00.00 setiap harinya. Hal ini sangat bermasalah, terutama dirinya yang memiliki seorang anak perempuan yang masih berusia dua tahun. Subyek mengeluhkan bahwa anaknya lebih dekat dengan pengasuh dan tidak ingin bermain dengan dirinya pada saat akhir pekan. Hal ini dirasa subyek merupakan dampak dari kesibukannya. Meskipun sudah selesai jam bekerja di kantor, subyek yang bekerja sebagai di bidang marketing harus banyak bertemu klien di luar jam kerja hingga larut malam. Pada akhir pekan, subyek terkadang masih harus bertugas ke luar kota bahkan ke luar negeri. Bahkan, subyek masih harus membawa beberapa pekerjaannya ke rumah untuk diselesaikan (MAB, Komunikasi Personal, 2017).

Selain permasalahan untuk urusan keluarga dan urusan kantor, subyek juga merasa toleransinya yang berkurang pada bawahan, membuat subyek mudah marah dan kurang bisa membimbing bawahannya dengan baik. Aleem dan Danish (2008) mengatakan bahwa wanita menikah yang bekerja memiliki tingkat kecemasan yang lebih tinggi daripada yang tidak $(\mathrm{t}=22,5$ dan $p<$ 
0,01). Karyawan wanita yang sudah menikah memiliki emosi, perasaan yang lebih mudah terpengaruh ketika dihadapkan pada tanggunjawab pada keluarga yang harus jalan bersamaan dengan tanggungjawab pekerjaan, sehingga membuatnya lebih mudah cemas dan hal ini membuat karyawan wanita lebih mudah terpegaruh kinerjanya. Subyek bahkan sempat berpikir untuk keluar dari pekerjaannya karena masalah hubungannya di kantor dan masalah anaknya yang mulai menghindari dirinya saat di rumah, namun subyek sangat berat untuk melakukannya karena subyek merasa dirinya memiliki tanggung jawab untuk tetap harus bekerja untuk membantu ekonomi keluarganya. Subyek mengatakan bahwa permasalahan ini membuatnya merasa sangat tertekan, tuntutan di kantor nya terus meningkat, sedangkan dirinya juga merasa tetap harus dapat berada bersama keluarganya dengan keadaan tersebut (MAB, Komunikasi Personal, 2017).

Stres memiliki dampak negatif terhadap performa kerja seseorang. Ketika stres, individu akan berada dalam kondisi kepatuhan nilai moral yang rendah, karyawan akan sering bolos, kualitas kerja yang kurang baik, dan penurunan performa kerja hingga pada tahap seorang karyawan keluar dari pekerjaannya (Huang, 2012). Respon stres negatif ini biasanya dikenal dengan distress (McGowan, 2006).

Tuntutan kerja yang tinggi pada karyawan akan menyebabkan stres. Kondisi stres dapat berupa pengalaman emosional yang tidak menyenangkan yang berhubungan dengan perasaan takut, cemas, terganggu, marah, sedih, dan depresi (Motowidlo, Packard, \& Manning, dalam Wu, 2011). Stres juga membuat adanya penyimpangan kondisi psikologis dari fungsi normal (Richardson \& Rothstein, dalam Wu, 2011). Stres kerja sering dilihat sebagai hal yang disfungsional dan berpengaruh menurunkan kualitas dan kuantitas kerja (Wu, 2011).

Namun disisi lain, penelitian menemukan adanya dampak positif dari stres kerja. Ketika muncul stresor, hal ini akan diterima sebagai sebuah tantangan yang meningkatkan dorongan internal dalam diri individu dan kemudian memberikan hasil performa yang lebih baik. Saat merasa stres, pada awalnya individu akan merasa cemas, namun setelah itu seseorang akan merasakan bahwa stres nya membuat dirinya termotivasi untuk mengerjakan dengan mengeluarkan kemampuan yang maksimal dan justru menghasilkan kinerja yang lebih baik dan optimal (LePine, Podsakoff \& LePine, 2005). Respon positif ini biasanya dikenal dengan eustress (McGowan, 2006).

Inkonsistensi yang ditemukan ini yang membuat peneliti melihat adanya faktor lain yang mengatur hubungan antara stres kerja dan kinerja pada karyawan. Ditemukan adanya faktor psychological detachment yang memiliki pengaruh yang positif terhadap kinerja. Ketika individu dapat memisahkan diri dengan pekerjaan nya secara mental dan fisik, seseorang akan menunjukan kinerja yang lebih baik. Hal ini yang mengatur hubungan ketika seseorang yang mengalami stres dalam bekerja, tetapi dapat memisahkan dirinya diduga akan membuat peforma kerjanya lebih baik (Sonnetag, 2012)

Penelitian lain juga pernah menunjukkan peran psychological detachment pada hubungan dua variabel penelitian yang lainnya. Penelitian menunjukkan peran psychological detachment sebagai moderator hubungan antara stresor dan burnout (Etzion, 1998). Selain itu, psychological detachment juga memoderasi hubungan antara stres dan reaksi strain (Sonnetag, et al., 2010). Berdasarkan beberapa tinjauan tersebut, maka peneliti mengajukan variabel psychological detachment sebagai moderator, khususnya pada karyawan wanita yang bekerja. Maka dari itu, 
peneliti membuat penelitian ini yang berjudul "Peran psychological detachment sebagai moderator hubungan antara stres kerja dan kinerja".

\section{Rumusan Masalah}

Setelah melakukan pendalaman mengenai hubungan antara stres kerja dan kinerja, masih ditemukannya inkonsistensi hasil dari kedua variabel anatara stres kerja dan kinerja. Penilitian menunjukkan bahwa stres kerja memiliki hubungan yang negatif dengan kinerja. Stres kerja membuat karyawan memiliki pengalaman emosional yang tidak menyenangkan yang berhubungan dengan perasaan takut, cemas, terganggu, marah, sedih, dan depresi (Motowidlo, Packard, \& Manning, dalam Wu, 2011). Stress juga membuat adanya penyimpangan kondisi psikologis nya dari fungsi normalnya (Richardson \& Rothstein, dalam Wu, 2011). Stres kerja sering dilihat sebagai hal yang disfungsional dan berpengaruh menurunkan kualitas dan kuantitas kerja (Wu, 2011).

Namun selain itu juga ditemukan adanya pengaruh yang positif dari stres kerja terhadap kinerja, Saat merasa stress, pada awalnya individu akan merasa cemas, namun setelah itu seseorang akan merasakan bahwa stress nya membuat dirinya termotivasi untuk mengerjakan dengan mengeluarkan kemampuan yang maksimal dan justru menghasilkan kinerja yang lebih baik dan optimal (LePine, Podsakoff, \& LePine, 2005).

Melihat adanya inkonsistensi ini, peneliti mencoba menjelaskan adanya pengaruh dari variabel psychological detachment sebagai moderator hubungan kedua variabel tersebut. Psycholgical detachment yang menunjukkan kemampuan dan kemauan seeorang untuk dapat memisahkan diri dari pekerjaan di luar waktu bekerja ditemukan menunjukkan kinerja yang lebih baik dibandingkan yang tidak dapat melakukannya. Untuk itu, ditarik kesimpulan untuk meneliti "apakah psychological detachment dapat berperan sebagai moderator hubungan antara stres kerja dengan kinerja?"

\section{METODE PENELITIAN \\ Partisipan}

Partisipan yang masuk kriteria penelitian ini adalah wanita karir. Susanto dan Haryanto (2010) menyimpulkan wanita karir sebagai wanita yang bekerja pada suatu organisasi atau perusahaan dengan tujuan mencapai kenaikan posisi dalam pekerjaannya yang dapat diperoleh dengan menambah pengalaman, keahlian yang dimiliki, perencanaan untuk kemajuan pekerjaannya dalam suatu periode waktu. Meningkatnya posisi pekerjaan maka akan menyebabkan bertambahnya tanggung jawab dalam pekerjaan, tingkat otoritas, komitmen, serta naiknya upah pekerjaan. Wanita karir yang dimaksud dalam penelitian ini termasuk yang sudah menikah maupun belum menikah tanpa adanya batasan usia, dan juga tidak ada batasan lama bekerja dalam penelitian ini. Pada pelaksanaan penelitian ini mendapatkan sebanyak 126 partisipan, namun 26 nya tidak dapat digunakan karena tidak termasuk dalam kriteria penelitian. Dari 100 orang partisipan, seluruhnya berjenis kelamin wanita, terdapat 39 orang $(35,1 \%)$ sudah menikah, dan 61 orang $(55 \%)$ yang belum menikah. Sedangkan dilihat berdasarkan posisi, terdapat 73 orang $(73 \%)$ adalah staf, 15 orang (15\%) supervisor, 11 orang (11\%) manajer, dan 1 orang (1\%) lainnya.

Peneliti juga menanyakan aktivitas yang dilakukan diluar pekerjaan, terdapat 17 orang (17\%) melakukan pekerjaan sampingan, 53 orang (53\%) liburan/refreshing/jalan-jalan, 17 orang (17\%) mengurus keluarga, dan 13 orang (13\%) melakukan kegiatan lainnya. 
Teknik pengambilan sampel pada penelitian ini menggunakan teknik non-probability sampling, yaitu convenience sampling. Peneliti akan memberikan kuisioner kepada rekan partisipan yang memenuhi kriteria penelitian. Kemudian, rekannya akan menyebarkan kembali kepada orang lain yang sesuai dengan kriteria penelitian.

\section{Pengukuran Penelitian}

Penelitian ini megukur tiga variabel, yaitu (a) Kinerja, (b) stres kerja dan (c) psychological detachment yang seluruhnya menggunakan bahasa Indonesia.

\section{Skala Kinerja}

Untuk mengukur kinerja dari karyawan, peneliti menggunakan alat ukur yang dikembangkan oleh Fakultas Psikologi Universitas Tarumanagara berdasarkan konsep dari Koopsman. Alat ukur ini yang terdiri dari 47 butir pertanyaan dengan skala Likert satu sampai lima. Semakin tinggi skor pada variabel ini berarti partisipan semakin dapat menjalankan tugasnya dan mencapai tujuan perusahaan. Terdapat 13 butir pernyataan yang mengukur dimensi task performance dari kinerja, dan di dalam nya terdapat empat butir negatif. Contoh butir posiitif dari dimensi ini adalah "Saya bekerja untuk memenuhi target yang ditetapkan". Sedangkan contoh butir negatif adalah "saya sulit menetapkan prioritas dalam pekerjaan saja". Peneliti melakukan uji reliabilitas dengan menggunakan nilai alpha cronbach dan mendapatkan koefisien sebesar 0,843 . Kemudian validitas tiap butir nya berada diatas 0,2 yang berarti semua butir pada dimensi ini valid dan tidak ada yang dibuang

Dimensi kedua adalah contextual performance terdiri dari 16 butir yang seluruhnya adalah item positif. Contoh butirnya berbunyi seperti "Saya terbuka terhadap kritik atas pekerjaan saya", "saya mampu bekerja sama dengan baik". Pada uji reliabilitas, memiliki alpha cronbach sebesar 0,895 dan validitas setiap butirnya berada diatas 0,2 yang berarti semua butir pada dimensi ini valid dan tidak ada yang dibuang. Dimensi adaptive performance terdiri dari 8 butir yang seluruhnya adalah item positif yang contohnya berbunyi seperti "saya menjaga agar pengetahuan yang berhubungan dengan pekerjaan saya tetap up to date". Pada uji reliabilitas, memiliki alpha cronbach sebesar 0,897 dan validitas setiap butirnya berada diatas 0,2 yang berarti semua butir pada dimensi ini valid dan tidak ada yang dibuang. Terakhir dimensi CWB terdiri dari 10 butir yang seluruh butirnya adalah positif dan berbunyi seperti "saya berbicara kepada rekan kerja mengenai hal negatif dari pekerjaan saya". "saya sengaja bekerja dengan lambat" Pada uji reliabilitas, memiliki alpha cronbach sebesar 0,806 dan validitas setiap butirnya berada diatas 0,2 yang berarti semua butir pada dimensi ini valid dan tidak ada yang dibuang.

\section{Stres Kerja}

Alat ukur variabel ini menggunakan Job Stres Survey yang dikembangkan oleh Fakultas Psikologi Universitas Tarumanagara berdasarkan konsep dari Vagg dan Speilberger (1999). Terdiri dari 68 pertanyaan yang terdiri dari 34 menggambarkan severity dan 34 butir berikutnya menggambarkan frekuensi. Menurut Perewe dan Gansterstres (Hamid et al, 2015), stres didefinisikan sebagai proses yang dilalui karyawan yang membuatnya merasa, menilai dan menanggapi tuntutan pekerjaan. Semakin tinggi skor stres kerja seseorang, semakin sering mengalami kejadian yang membebankannya. Vagg dan Speilberger mengatakan bahwa stres kerja merupakan interaksi dari tingkat seberapa parah suatu kejadian (severity), dengan seberapa sering orang merasakan hal hal tersebut. 
Bagian pertama yang mengukur severity memiliki pertanyaan berskala empat, mulai dari skor 1 menunjukan tidak membebankan, dan skor 4 untuk sangat membebankan. Sedangkan pada frekuensi juga berskala 4, dengan skor 1 menunjukan tidak pernah dan 4 menggambarkan selalu. Skor akhir dari stres kerja diperoleh dari hasil perkalian pasangan butir severity dan frekuensi. Contoh, pada butir severity partisipan memberi skala 4, dan skor frekuensi juga empat pada butir "mengalami sifat negatif dari atasan", maka skor stres kerja nya menjadi 16.

Berdasarkan uji reliabilitas, alat ukur variabel ini memiliki koefisien alpha cronbach sebesar 0,942 dan untuk validitas seluruh butirnya berada diatas 0,2, maka menyatakan bahwa seluruh butirnya valid dan tidak ada yang dibuang.

\section{Skala Psychological Detachment}

Alat tes ini diterjemahkan ke dalam Bahasa Indonesia dari alat ukur dari Sonnetag yang terdiri empat butir dengan skala likert satu sampai lima. Sonnetag and Fritz (2007) mendefinisikan psychological detachment sebagai keadaan di mana individu mampu memisahkan diri secara mental dari perkerjaannya, dengan kata lain, individu yang melakukan psychological detachment tidak memikirkan isu-isu mengenai pekerjaannya ketika berada di luar waktu dan ruang kerja. Semakin tinggi skor psychological detachment, berarti individu semakin dapat memisahkan diri dan tidak memikirkan pekerjaannya di luar waktu bekerja.

Variabel ini merupakan unidimensional, Kuisioner ini memiliki intruksi untuk partisipan menjawab pernyataan sesuai dengan dirinya pada saat berada di luar waktu bekerja. Contoh pada variabel ini adalah "Melupakan pekerjaan anda". "tidak memikirkan tentang pekerjaan anda sama sekali". Berdasarkan uji reliabilitas dengan menggunakan alpha cronbach, didapatkan koefisien sebesar 0,863 . Serta validitas setiap butirnya berada diatas 0,2 yang berarti semua butir ini valid dan tidak ada butir yang dibuang.

\section{Prosedur Penelitian}

Setelah membuat kuisioner dalam bentuk dua versi yaitu kuisioner yang akan disebarkan secara hardcopy dan kuisioner yang dibuat di google form. Pada metode pertama, peneliti mulai memberikan kuisioner fisik kepada rekan dari peneliti untuk disebarkan kepada temannya di kantor. Sebelumnya, peneliti menyusun dan mencetak kuisioner penelitian ini yang terdiri dari informed consent, biodata, baru alat ukur penelitian yang dijadikan satu bundle. Setelah menerima kuisioner ini, partisipan akan membaca dan mengisi lembar informed consent, biodata, alat ukur psychological detachment, alat ukur kinerja, baru alat ukur stres kerja. setelah selesai mengisi, partisipan mengumpulkan kembali kuisioner yang sudah diisi.

Pada metode penyebaran kedua, peneliti menyebarkan link kuisioner kepada rekan lainnya melalui layanan pesan di smartphone peneliti. Peneliti awalnya menjelaskan maksud dari kuisioner yang diberikan dan meminta rekannya memberikan link kepada rekan kerja yang juga memenuhi kriteria peneliti yaitu perempuan yang bekerja. Setelah menerima link, dan mengakses link tersebut, partisipan akan langsung terhubung dengan google form yang telah dibuat peneliti yang urutannya sama seperti kuisioner hardcopy. Setelah selesai, respons dari partisipan akan tersimpan otomatis pada google doc. Pada saat sudah selesai, peneliti megunduh form nya, kemudian memindahkan ke program SPSS.

Pengambilan data dimulai pada awal bulan Mei 2017, kegiatan ini berlangsung hingga tanggal 26 Mei 2017. Setelah melakukan rekap dari kuisioner baik dari google form dan kuisioner langsung, peneliti mendapatkan sebanyak 120 partisipan. Namun, 20 diantaranya tidak masuk 
dalam kriteria penelitian. Untuk itu, partisipan yang didapat untuk penelitian ini berjumlah 100 orang.

\section{HASIL DAN PEMBAHASAN}

Setelah melakukan uji normalitas, dapat disimpulkan bahwa seluruh variabel penelitian ini berdistribusi normal. Kemudian peneliti melakukan uji interaksi untuk mengetahui peran variabel moderator psychological detachment pada penelitian ini. Hal pertama yang dilakukan peneliti dalam menyelidiki peran moderator adalah melakukan crosscheck hubungan variabel independen yaitu stres kerja dan kinerja. Untuk itu, peneliti melakukan uji regresi antara kedua variabel tersebut. Hasilnya menunjukan nilai $r=-0,380$ dengan $p=0,000<0,05$. Hal ini berarti terdapat hubungan negatif yang sangat signifikan antara stres kerja dan kinerja. Sehingga semakin tinggi stres kerja pada partisipan, maka semakin rendah kinerjanya. Kemudian untuk mengetahui peran psychological detachment sebagai variabel moderator, peneliti melakukan pengelompokan setiap variabel penelitian menjadi kelompok rendah dan tinggi. Untuk penggolongan partisipan, nilai variabel kinerja dikelompokan menjadi dua bagian. Menurut ukuran nilai standar skor, nilai $\mathrm{z}<0,50000$ masuk sebagai kategori rendah, dan nilai $\mathrm{z}>$ 0,50000 masuk dalam kategori tinggi.

Hasilnya, didapatkan pada kelompok psychological detachment rendah, hubungan stres kerja dan kinerja menunjukan angka negatif $r=-0,422$ dan $p=0,023<0,05$. Hal serupa juga terjadi pada kelompok partisipan dengan psychological detachment tinggi, hubungan stres kerja dan kinerja adalah negatif $r=-0,443$ dan $p=0,013<0,05$. Hasilnya dapat dilihat lebih lanjut pada tabel 1 berikut ini.

Tabel 1. Analisis Kondisi Variabel Penelitian

\begin{tabular}{|c|c|c|c|}
\hline & $\begin{array}{l}\text { Psychological } \\
\text { Detachment } \\
\text { Rendah } \\
\end{array}$ & $\begin{array}{l}\text { Psychological } \\
\text { Detachment } \\
\text { Tinggi } \\
\end{array}$ & Interpretasi \\
\hline $\begin{array}{l}\text { Stres } \\
\text { Kerja } \\
\text { Tinggi }\end{array}$ & $\begin{array}{l}r=-0,638 \\
\mathrm{p}=0,035<0,05^{*}\end{array}$ & $\begin{array}{l}r=-0,097 \\
\mathrm{p}=0,837>0,05 \\
(\mathrm{TS})\end{array}$ & $\begin{array}{l}\text { Psychological detachment tidak berfungsi sebagai } \\
\text { moderator pada hubungan stres kerja tinggi baik pada } \\
\text { saat psychological detachment rendah ataupun tinggi. }\end{array}$ \\
\hline $\begin{array}{l}\text { Stres } \\
\text { Kerja } \\
\text { Rendah }\end{array}$ & $\begin{array}{l}r=0,742 \\
\mathrm{p}=0,151>0,05 \\
(\mathrm{TS})\end{array}$ & $\begin{array}{l}r=-0,699 \\
\mathrm{p}=0,005< \\
0,01 * *\end{array}$ & $\begin{array}{l}\text { Psychological detachment tidak berfungsi sebagai } \\
\text { moderator pada hubungan stres kerja rendah baik pada } \\
\text { saat psychological detachment rendah ataupun tinggi. }\end{array}$ \\
\hline
\end{tabular}

\section{KESIMPULAN DAN SARAN}

\section{Kesimpulan}

Psychological detachment tidak terbukti memoderasi hubungan antara stres kerja dan kinerja, dengan demikian juga menunjukan pada hipotesis penelitian ini tidak terbukti. Peneliti mencoba melakukan beberapa penelusuran untuk mengetahui penyebab hal ini dapat terjadi. Peneliti melihat kemungkinan dari dua sudut pandang, yaitu dari segi metode dan partisipan penelitian. 
Ditinjau dari segi metode, peneliti melihat adanya kekurangan pada alat ukur psychological detachment yang digunakan. Alat ukur ini hanya terdiri empat butir dan bersifat self-report. Partisipan pun melakukan wawancara kepada beberapa partisipan penelitian setelah penelitian ini untuk mengetahui pengertian psychological detachment menurut mereka. Hasilnya, seorang partisipan yang masuk dalam kategori tinggi pada variabel psychological detachment. Partisipan ini sudah menikah dan memiliki anak mengatakan bahwa dirinya mampu melupakan pekerjaannya ketika bertemu dengan anaknya, partisipan juga mengatakan bahwa dirinya akan berpikir banyak kali untuk membawa pekerjaan ke rumah, karena menurutnya, dirinya hanya digaji untuk di waktu bekerja dan disaat lembur saja. Ketika berada di luar waktu itu, partisipan tidak bersedia dan tidak menyukainya. Namun, meskipun demikian, partisipan yang mengatakan bahwa dirinya masih sering membalas pesan singkat atau telepon mengenai pekerjaan pada saat sedang tidak bekerja. Menurutnya, hal ini masih dalam batas toleransinya. Sehingga disimpulkan bahwa, subyek sudah melakukan pemisahan diri atau psychological detachment dengan pekerjaan dengan cara yang demikian.

Peneliti juga menemukan beberapa jurnal temuan yang menunjukan adanya faktor lain yang memengaruhi kinerja. Peneliti menemukan bahwa stres kerja tidak berdampak langsung pada kinerja, melainkan memengaruhi strain dari individu yang berhubungan dengan cognitve failure yang membuat orang yang stres mengalami penurunan kinerja untuk dapat tetap fokus pada pekerjaan. Penelitian ini juga menemukan bahwa psychological detachment lebih tergantung pada stres yang dialami dibandingkan dengan individu itu sendiri (Safstrom \& Hartig, 2013).

Selain itu, peneliti juga menemukan penelitian dari National Taiwan Ocean University pada tahun 2016 yang meneliti tentang stres. Penelitian ini menunjukkan bahwa stres memiliki dua sisi seperti mata koin, yaitu positif dan negatif. Hal ini dipengaruhi dari cara individu menanggapi stres itu sendiri. Ketika stres sudah diterima seseorang sebagai sebuah hal yang di luar kapasitasnya, maka hal ini diterima sebagai stres negatif, atau biasa disebut distres (Gadzela dalam Gaol, 2016). Sedangkan ketika stres diterima sebagai suatu yang positif atau disebut eustres, maka yang akan terjadi adalah peningkatan kinerja dan kesehatan (Greenberg, dalam Gaol, 2016). Peneltiian di Taiwan juga menunjukan bahwa eustres merupakan faktor penentu yang mendorong karyawan untuk mencapai kerja maksimal dan meningkatkan kepuasan kerja (Jarinto, 2010).

Penelitian lain menunjukan bahwa stres kerja dan kinerja memiliki hubungan yang bersifat kurvalinier. Hal ini berarti, kinerja dapat menjadi optimal jika stres kerja berada pada level ratarata/ sedang. Ketika stres kerja berada pada level rendah atau tinggi, justru akan menurunkan kinerja (Jamal, 1984). Namun, setelah menemukan penelitian ini, peneliti kembali melakukan pengecekan hubungan stres kerja dan kinerja pada kondisi stres kerja sedang. Hasilnya ditemukan tidak terdapat hubungan yang signifikan pada stres kerja sedang dan kinerja baik pada kondisi psychological detachment rendah maupun tinggi.

Berdasarkan tinjauan beberapa jurnal yang didapatkan peneliti tersebut, peneliti menilai adanya faktor lain yang membuat hubungan stres kerja dan kinerja ini tidak terbukti. Hal yang ditemukan yaitu hasil penelitian yang menunjukan ketika seseorang sudah menerima stres sebagai suatu hal yang negatif dan berada di luar kemampuannya, hal ini tentu berdampak negatif juga pada individu. Sedangkan apabila diterima sebagai sesuatu yang positif, hal ini dapat berdampak positif pada kinerja. Hal lain juga menyatakan ternyata psychological detachment lebih tergantung pada stres yang dialami dibandingkan dari dengan individu itu sendiri (Safstrom dan Hartig, 2013). 


\section{Saran}

Berdasarkan pada kekurangan penelitian ini, peneliti berharap bahwa variabel psychological detachment dapat diteliti lebih lanjut, khususnya di Indonesia. Variabel ini merupakan variabel yang masih jarang diteliti di Indonesia. Peneliti menemukan banyaknya penelitian di luar negeri yang menunjukan manfaat dari psychological detachment. Meskipun pada penelitian ini tidak terbukti, peneliti berharap, penelitian selanjutnya dapat melakukan penelitian yang lebih baik dengan lebih memperhatikan pada kriteria subyek, serta masukan peneliti terhadap alat ukur psychological detachment. Alat ukur ini juga masih bersifat unidimensional, peneliti melihat perlunya adanya pengembangan seperti adanya dimensi pada variabel ini. Misalnya, penilaian psychological detachment tidak hanya dinilai secara umum saja, namun juga ditinjau dari segi fisik, kognitif dan perilaku individu yang dapat lebih menggambarkan seorang individu dapat melakukan psychological detachment atau tidak. Selain itu, pertimbangan perlu adanya pengembangan alat ukur ini sesuai dengan budaya yang ada di Indonesia. Hal ini disarankan oleh peneliti karena ditemukan pada subyek penelitian ini, mengatakan bahwa dirinya bisa memisahkan diri dengan pekerjaan nya atau psychological detachment meskipun masih sering menerima telepon soal pekerjaan.

Selain itu, peneliti juga melihat perlunya melakukan penelitian tentang psychological detachment secara ekperimental, bukan self-report. Penilaian akan pelaksaaan psychological detachment dinilai oleh orang lain yang mengobservasi partisipan

Peneliti memberikan masukan pada para pekerja untuk dapat mengolah stres yang ada pada dirinya, karena seperti yang telah dikatakan sebelumnya, bahwa stres bersifat seperti dua mata koin. Ketika seseorang dapat mengolah stres nya menjadi eustres, hal ini akan membantu dalam meningkatkan kinerja, dan ditambah jika stres dapat dikontrol oleh individu, disertai dengan melakukan psychological detachment, maka hal ini akan membantu subyek kembali bekerja dengan baik dan menunjukan kinerja yang lebih optimal setelah melalui proses recovery yang didapat dari proses psychological detachment.

\section{Ucapan Terima Kasih (Acknowledgement)}

Terima kasih kepada partisipan yang terlibat dalam penelitian. Terima kasih kepada Program Studi Magister Psikologi Universitas Tarumanagara atas fasilitas pengerjaan penelitian ini. Terima kasih juga diucapkan kepada seluruh dosen Magister Psikologi Universitas Tarumanagara yang membantu dan menunjang pelaksaaan penelitian ini sehingga dapat selesai.

\section{REFERENSI}

Aleem, S., Danish, L. (2008). Marital satisfaction and anxiety among single and dual career women. Journal of The Indian Academy Of Applied Psychology. 34, 141-144

Chaplin, J. P. (2008). Kamus lengkap psikologi. Jakarta: Raja Grafindo Persada.

Demerouti, E. (2006). Job characteristic, flow, and performance : the moderating role of conscientiousness. Journal of Occupational Health Psychology, 11(3), 266-280

Etzion, D., Eden, D., Lapidot. Y. (1998). Relief from job stressor and burnout : reserve service as respite. Journal of Applied Psychology. 83(4), 577-585

Gaol, N. T. L. (2016). Teori stres : stimulus, respons, dan transaksional. Buletin Psikologi. 24(1), $1-11$ 
Huang, J. L., Ryan, A. M., Zabel, K. L., \& Palmer, A. (2013). Personality and adaptive performance at Work: A Meta-analytic Investigation. Journal of Applied Psychology

Jamal, M. (1984). Job stress and job performance controversy : an empirical assesment. Organizational Behavior Human Performance. 33(1), 1-21

Jarinto, K. (2010). Eustress: A key to improving job satisfaction and health among Thai managers comparing US, Japanese, and Thai companies using SEM analysis. NIDA Development Journal, 50(2), 100-129.

Kahn, R. L., Wolfe, D. M., Quinn, R. P., Snoek, J. D., \& Rosenthal, R. A. (1964). Organizational stress: Studies in role conflict and ambiguity. New York, NY: Sage.

Koopsman, L., (2014). Measuring Individual work performance. Zutphen, NLD: CPI Koninklijke Wöhrmann

Lepine, J. A., Podsakoff, N, P., Lepine, M. A. (2005). A meta-analytic test of the challenge stressor-hindrance stressor framework: an explanation for inconsistent relationships among stressors and performance. Academy of Management Journal. 48(5). 764-775

McGowan, J., Gardner, D., Fletcher, R. (2006). Positive and negative affective outcomes of occupational stress. New Zealand Journal of Psychology 35(2), 92-98

Pulakos. E, D., Arad, S. Donovan, M.A., Plamondon. K.E. (2000) Adaptability in the workplace: Development of taxonomy of adaptive performance. Journal of Applied Psychology $85(4), 612-624$

Penney, L. M., dan Spector, P. E. (2002). Narcissism and counterproductive work behavior: Do bigger egos mean bigger problems?. International Journal of Selection and Assessment, 10, (1): 126-134.

Safstrom, M., Hartig, T. (2013). Psychological detachment in the relationship between job stressor and strain. Behavioral Science. 3, 418-433

Sonnentag, S. (2002). Psychological management of individual performance. British library catalolguing in publication data. New Delhi, India.

Sonnentag, S., Binnewies. (2010). Staying well and engaged when demands are high: the role of psychological detachment. Journal of Applied Psychology. 95(5). 965-976

Sonnentag, S. (2012). Psychological detachment from work during leisure time: the benefits of mentally disengaging from work. Current Direction in Psychological Science. 21(2), 114-118.

Sonnentag, S., Fritz, C. (2007). The recovery experience questionnaire: development and validation of a measure for assessing recuperation and unwinding from work. Journal of Occupational Health Psychology. 12(3), 204-221

Sonnetag, S., Bayer, U. (2005). Switching off mentally: predictors and Consequences of psychological detachment from work during off-job time. Journal of Occupational Health Psychology, 10(4), 393-414

Stewart, W., Barling, J. (1996). Daily work stress, mood and interpersonal job performance : a mediational model. Work \& Stress. 10(4), 336-351

Susanto, P., \& Haryoko, F. (2010). Gambaran konsep diri pada wanita berkarier sukses yang belum menikah. Insan, 2 (1), 11-20.

Tangkilisan, H. N. (2007). Manajemen publik. Jakarta: Grasindo.

Tohardi, A. (2002). Pemahaman praktis manajemen sumber daya manusia. Bandung: Mandar Maju.

Vagg, P. R., \& Spielberger, C. D. (1999). The job stress survey: assessing perceived severity and frequency of occurrence of generic sources of stress in the workplace. Journal of Occupational Health Psychology, 4(3), 288-292. 
Voirin, A. C., Roussel, P. (2012). Adaptive performance: a new scale to measure individual performance in organizations. Canadian Journal of Administrative Sciences. 29, 280-293

$\mathrm{Wu}, \mathrm{Y}$. (2011). Job stress and job performance among employee in taiwanese sector : the role of emotional inteligence. Social behavior and personality. 39(1), 21-32

Zendehdelan, A. (2013). Home qualities that makes it as a health supportive place "long-term patients' perception and preferences". Academic journal of interdiciplinary studies. 2(8).

Agustina. (2016). Wahyu Hartanto menjadikan karyawan ujung timbak kesuksesan. Diunduh dari https://news.rumahrei.com/featured/wahyu-hartanto-menjadikan-karyawan-ujungtombak-kesuksesan/

Muklis, C. A. (2016, Februari 26). Kehadiran MEA geliatkan industri pelumas nasional. Tribun News. Diunduh dari http://jambi.tribunnews.com/2016/02/26/kehadiran-mea-geliatkanindustri-pelumas-nasional.

Rostanti, Q., dan Rini, C. L. (5 Januari 2016). Ini Kesiapan Pemerintah menghadapi MEA. Diunduh dari http://www.republika.co.id/berita/ekonomi/makro/16/01/05/o0hnma299ini-kesiapan-pemerintah-menghadapi-mea.

Suryanto. (2015, Agustus 13). Kesiapan Indonesia menghadapi masyarakat ekonomi Asean 2015. $R R I$. Diunduh dari http://www.rri.co.id/voi/post/berita/96494/fokus/kesiapan_indonesia_menghadapi_masya rakat_ekonomi_asean_2015.html 